\title{
Building capacity for co-operative governance as a basis for integrated water resource managing in the Inkomati and Mvoti catchments, South Africa"
}

\author{
Colvin $\mathrm{J}^{1 *}$, Ballim $\mathrm{F}^{2}$, Chimbuya $\mathbf{S}^{3}$, Everard $\mathbf{M}^{4}$, Goss $\mathrm{J}^{5}$, Klarenberg $\mathbf{G}^{6}$, Ndlovu $\mathbf{S}^{7}$, \\ Ncala $D^{5}$ and Weston $D^{8}$ \\ ${ }^{1}$ Open University, Research School, Walton Hall, Milton Keynes, United Kingdom MK7 6AA \\ ${ }^{2}$ Water for Africa, 9 Hampden Road, Morningside, Durban 4001, South Africa \\ ${ }^{3}$ Khanya-aicdd, 16A President Steyn Avenue, Westdene, Bloemfontein 9301, South Africa \\ ${ }^{4}$ Environment Agency, Rio House, Waterside Drive, Aztec West, Almondsbury, Bristol BS32 4UD, England \\ ${ }^{5}$ Cinnabar Global Circle cc, 19A Bristol Road, Parkwood 2193, South Africa \\ ${ }^{6}$ Mvula Trust, PO Box 32351, Braamfontein 2017, South Africa \\ 7Inkomati Catchment Management Agency, Private Bag X11214, Nelspruit 1200, South Africa \\ ${ }^{8}$ Department of Water Affairs and Forestry, Private Bag X313, Pretoria 0001, South Africa
}

\begin{abstract}
South Africa's National Water Act and National Water Resource Strategy set out an ambitious vision for Integrated Water Resources Management including a strong focus on the redistribution of water resources towards the poor and on empowering historically disadvantaged communities. To achieve this vision the Department of Water Affairs \& Forestry (DWAF) has been pursuing a programme for devolving powers to 19 stakeholder-led catchment management agencies (CMAs) and more locally, transforming irrigation boards into more inclusive water user associations (WUAs), as well as creating new associations.

Co-operative governance is a core principle of this programme. As well as being enshrined in South Africa's constitution, this principle is seen as key to enabling CMAs to implement their core functions, which include co-ordinating the activities of water users and water management institutions within their water management area. For WUAs also, the principle of co-operative governance is key to building engagement between White commercial farmers and emerging Black farmers, as well as (in some cases) engaging with a wider set of stakeholder interests including local government and environmental interests.

Despite a commitment to the principle of co-operative governance, individual and institutional capacity for facilitating co-operative development processes is in relatively short supply within the South African water sector. This paper describes work-in-progress to build capacity in this area, working with:

- DWAF's national Institutional Governance team

- The Inkomati CMA (ICMA), the first of South Africa's new catchment management agencies

- Two irrigation boards and a number of other stakeholders in the Mvoti catchment - with a view to the development of an appropriate institutional arrangement (WUA or otherwise) for the co-operative governance of this catchment.

This paper focuses on the development of an interactive approach to capacity building in each of these three sites, drawing from a broad portfolio of approaches variously described as social learning, social appraisal, or whole system development. In the Inkomati we have worked primarily with the whole system approach known as Future Search, whereas in the Mvoti we have used the U-process and social appraisal as guiding metaphors and design principles.

This paper describes some of our achievements, challenges and reflections to date, and argues that the interactive approaches we have been taking are better suited to the implementation of DWAF's institutional reform processes than the more established, top-down approaches, which involve issuing guidance, supported by training programmes. The paper concludes with a discussion of the implications for scaling up these types of approaches across the South African water system as a whole, and for the practice of integrated water resource management.
\end{abstract}

Keywords: adaptive IWRM, catchment management agencies, cooperative governance, dialogue, interactive capacity building, social learning, water user associations

Revised version. Originally presented at the International Conference on Integrated Water Resource Management (IWRM) entitled: Lessons from Implementation in Developing Countries which took place from 10 to 12 March 2008 in Cape Town, South Africa, at the Cape Town International Convention Centre.

* To whom all correspondence should be addressed.

푱 +271453836 722; fax: +27 1453836722 ; e-mail: j.d.colvin@open.ac.uk

\section{Introduction}

In ensuring the social and economic wellbeing of any nation, water plays a key role. In a water-stressed nation such as South Africa, the effective management of water resources is even more pivotal; South Africa's economic successes over the past century have in no small part been due to the ingenuity of its water managers. Thus considerable feats of engineering, dam building and inter-basin transfers have enabled South Africa to maximise use of its water resources and in particular, to grow 
the powerhouse of its economy in the Gauteng region, which itself has minimum local water resources (Turton, 2007).

However, throughout the twentieth century the benefits of these achievements were highly unevenly distributed, resulting in a large proportion of the population with very poor or inadequate access to water (Cullis and Van Koppen, 2007). In turn this has had serious repercussions on the health, resilience and dignity of many of South Africa's communities.

In the $21^{\text {st }}$ century, there is, furthermore, a very real risk that these inequities and vulnerabilities will become magnified, as increasing climate variability leads to even greater water stress. Much of South Africa's streamflow had already been harnessed by the 1980s, reaching what some would suggest is an absolute limit for economic viability (i.e. $60 \%$ capture, Rabie and Day, 1992) by the early 1990s (O'Keeffe et al., 1992). Today South Africa '...is confronted with basin closure in most of its significant systems, over-allocation of the resource in some basins by as much as $150 \%$, major pollution from strategic industry, and a highly skewed national plumbing system that reflects historic resource capture' (Turton, 2007: 17).

South Africa's new water laws and policies (RSA 1997, 1998; DWAF 2003, 2004a, 2007a) are designed to address these challenges as well as continue to build on its history of water engineering successes. Based on Integrated Water Resources Management (IWRM) principles, these water laws are widely recognised as some of the most progressive in the world, with an exemplary commitment to:

- A whole catchment approach to water security

- Empowerment of poor communities and the provision of water and sanitation for all

- Water for sustainable growth and development

- Effective governance based on stakeholder ownership and the devolution of relevant powers and functions to catchment and local levels.

Given the attention paid to devolved and stakeholder-led governance, these laws include a strong focus on institutional reform. Key features of this reform process include devolution of the water services authority role from the Department for Water Affairs and Forestry (DWAF) to district or local municipalities and, on the water resources management side, the devolution of power from DWAF to stakeholder-led catchment management agencies (CMAs) (The National Water Resources Strategy (2004a) provides for the progressive creation of 19 CMAs). More locally, this devolution includes the transformation of Irrigation Boards into more inclusive water user associations (WUAs), as well as the creation of new WUAs where no appropriate predecessor bodies exist.

Progressive policy thinking of this type demands progressive approaches to implementation. Without these, progress is likely to be slow, as has been evidenced for example by the serious delays in setting up the CMAs, with only 5 of 19 CMAs established by March 2008 of which only one of these, the Inkomati CMA (ICMA), is fully operational. The Governing Board of the Inkomati CMA was appointed in June 2005 and the ICMA became operational in May 2006. The Governing Board of the Breede-Overberg CMA was appointed in September 2007, whilst nominations for the Governing Board of the Crocodile West Marico CMA were submitted to the Minister in March 2008. The Olifants-Doorn and Gouritz initiated Advisory Committee processes in November 2007 and concluded these in May 2008.Similarly, of approximately 300 Irrigation Boards that require transformation to WUAs, as of March 2008 only some $20 \%$ had completed this process. The development of new WUAs, especially those for resource-poor farmers, has also proven difficult.

Within DWAF, two main approaches to capacity building can be distinguished, one of which falls within a more traditional mould and one within a more progressive mould. In the more traditional mould, there has been a strong emphasis on the development of guidance, with substantial volumes of guidance documents linked to the Strategic Framework for Water Services (2003) and the National Water Resource Strategy (2004a) being produced throughout the early 2000s. More recently this has been coupled with the development of training programmes. Both approaches tend to assume an approach to learning that can be characterised as one-way and expert-driven (These approaches to capacity building can be characterised as more 'traditional' in the sense that they assume a relatively passive and a-contextual model of learning in which those responsible for implementation, whose capacity needs to be built, are seen as 'empty vessels' waiting to be informed by a one way flow of procedural knowledge from the source of expertise that resides in the heads of policy makers (via their guidance documents).

In a more progressive mould, there have been a number of recent initiatives to introduce more interactive approaches to learning (These approaches to capacity building can be characterised as more 'progressive' in the sense that they assume a model of learning which is both active and interactive, and in which effective implementation results from those close to the action being supported to 'make sense' of what is needed by working out how to apply national policy thinking in the context of local realities). One example is the development of policy on multiple use water services approaches, which began life as part of a donor-funded, multi-country action research project in which local operational learning was later scaled up into a policy learning process (Van Koppen et al., 2006; DWAF, 2006). Another example, which provides the focus for this paper, is the capacity building work managed by DWAF's Water Management: Institutional Governance (WMIG) Department, to support the institutional reform process involving the development of CMAs and WUAs. This has drawn on several donor-funded programmes, one of which, arising from an initial collaboration with the Environment Agency (England and Wales), is reported here.

The collaboration with the Environment Agency has unfolded into a 4-year capacity- building programme known as Watercourse. The Watercourse can be described in terms of 2 cycles of inquiry, from which we draw out here some lessons for capacity building for implementation, and for IWRM, in the South African context and beyond. This paper considers the first 3 years of the programme, from April 2005 - March 2008.

\section{$1^{\text {st }}$ cycle of inquiry: April 05 - March 07}

(This first cycle of inquiry involved only three of the authors of this paper: John Colvin, Sizile Ndlovu and Derek Weston. Funding for John Colvin was from the UK's Department for Environment, Food \& Rural Affairs (Partners for Water \& Sanitation programme (PAWS)) and from the Environment Agency.)

In this paper we have chosen to tell the story of Watercourse from a developmental ('process') perspective, because process lies at the heart of our approach to capacity building, an approach which is based on action research/ action inquiry (Reason and Bradbury, 2001; Chalmers and Colvin, 2005; Khanya-aicdd and Southern Africa Trust, 2007). Over the past 3 years we can trace 2 broad cycles of inquiry, in which we start out with some design assumptions, then draw on these to shape our engagement in a 
series of conversations, out of which we (and hopefully others) then reflect on what we have learned (Fig. 1). Our intention here is that what we learn enables us to do better capacity building, and what others learn enables them better to implement South Africa's water policies.

Some key features of the $1^{\text {st }}$ cycle of inquiry are shown in Table 1. Our initial design assumptions were strongly shaped by the experiences of the first author in implementing IWRM approaches in the UK (as part of his work within the Environment Agency, supporting implementation the European Union Water Framework Directive (EC, 2000)), and the lessons learned from this (e.g. Orr et al., 2007). These included a recognition of the limitations of IWRM as a management strategy as it had come to be framed in the 1990s (ICWE, 1992; GWP, 2000), and of the need to reshape IWRM as a set of principles and practices which put learning, reflexivity and adaptation at their core

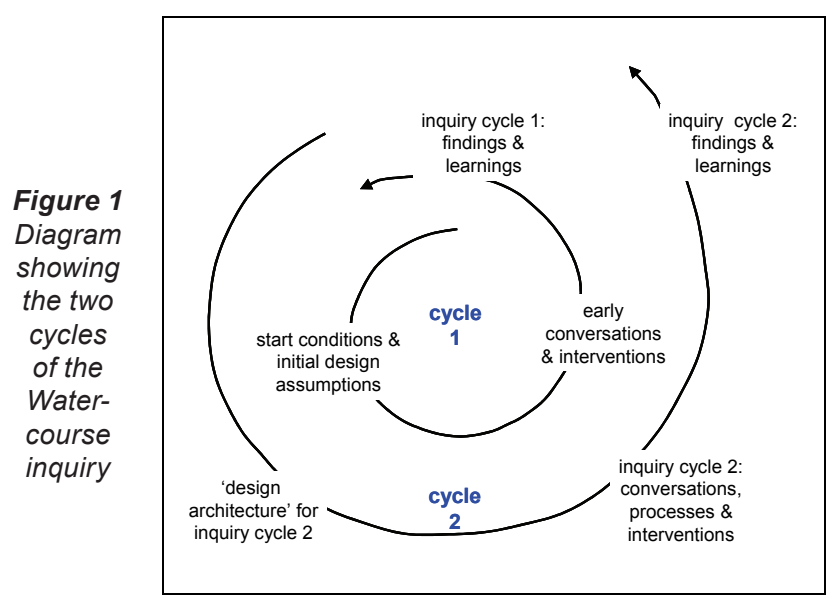

TABLE 1

Some key features of the first cycle of the Watercourse inquiry

\begin{tabular}{|c|c|c|c|}
\hline $\begin{array}{l}\text { (a) Start } \\
\text { conditions }\end{array}$ & \multicolumn{3}{|c|}{$\begin{array}{l}\text { - An enthusiastic partner in DWAF (Pretoria), and subsequently also in DWAF (KZN) and the ICMA } \\
\text { - } \quad \text { Permissive project resourcing from Defra (PAWS) and the Environment Agency } \\
\text { - Water Framework Directive) in England \& Wales (e.g. Collins et al., 2005; Orr et al., 2007) } \\
\text { - Emerging lessons from European research projects on implementing IWRM, and on reframing this as a } \\
\text { process of 'adaptive IWRM' (e.g. SLIM, 2004; Pahl-Wostl, 2007; Steyaert and Jiggins, 2007) } \\
\text { - Limited knowledge on the part of the first author of IWRM in developing countries }\end{array}$} \\
\hline \begin{tabular}{|l|} 
(b) Design \\
assumptions
\end{tabular} & \multicolumn{3}{|c|}{$\begin{array}{l}\text { - Action inquiry - start with a light-touch approach - learn through engagement - allow meaning and insight } \\
\text { to unfold as a 'spiral dynamic' } \\
\text { - Systemic inquiry - engage and learn from the South African 'water system' through engagement with a } \\
\text { wide cross-section of stakeholders; and at different levels of the system, from the national to the local - } \\
\text { notice where the system linkages are strong and where they are weak }\end{array}$} \\
\hline $\begin{array}{l}\text { (c) Capacity } \\
\text { building } \\
\text { conversations } \\
\text { and interven- } \\
\text { tions }\end{array}$ & \multicolumn{3}{|c|}{$\begin{array}{l}\text { - Exploratory conversations initially developed through a week of dialogue between the Environment Agency } \\
\text { (EA) and DWAF (Pretoria) in April } 2005 \\
\text { - Study visit by staff from DWAF Water Management: Institutional Governance (WMIG), DWAF KZN and } \\
\text { DWAF Free State offices to the UK (October 2005) designed to explore different approaches to capacity } \\
\text { building } \\
\text { Follow-up visits by EA and SLIM team members in March, August, December } 2006 \text { and March } 2007 \text { focus } \\
\text { on simple action learning and social learning workshops with staff from DWAF WMIG, DWAF KZN and } \\
\text { the ICMA, as well as a wide range of exploratory meetings through 1:1 meetings and others' workshops }\end{array}$} \\
\hline \multirow{2}{*}{$\begin{array}{l}\text { (d) Key } \\
\text { findings: } \\
\text { opportunities }\end{array}$} & Inkomati & KwaZulu-Natal & DWAF head office \\
\hline & $\begin{array}{l}\text { A set of guidelines for catch- } \\
\text { ment management strategy } \\
\text { development (DWAF 2007) that } \\
\text { emphasised a learning (transfor- } \\
\text { mational) approach } \\
\text { Interest from the ICMA govern- } \\
\text { ing board to experiment with a } \\
\text { learning approach, in engaging } \\
\text { with stakeholders around the } \\
\text { development of the Inkomati } \\
\text { Catchment Management Strat- } \\
\text { egy }\end{array}$ & $\begin{array}{l}\text { Enthusiasm within the catch- } \\
\text { ment management (CM) team } \\
\text { to deepen their learning process } \\
\text { around some specific pathfinder } \\
\text { studies - given the geography } \\
\text { of the Mvoti to Umzimukulu } \\
\text { there was a particular interest in } \\
\text { looking at WUA development in } \\
\text { two sub-catchments: the Mvoti } \\
\& \text { the Umzimkulu (subsequently } \\
\text { we focused only on the first of } \\
\text { these) }\end{array}$ & $\begin{array}{l}\text { High levels of commitment } \\
\text { within the WM:IG department; } \\
\text { WM:IG positioned as a 'path- } \\
\text { finding group', supporting } \\
\text { innovation within DWAF; } \\
\text { A willingness and enthusiasm } \\
\text { to learn and to co-create an } \\
\text { 'architecture of learning' (War- } \\
\text { burton et al., 2007) fit for the } \\
\text { South African context }\end{array}$ \\
\hline $\begin{array}{l}\text { (e) Key } \\
\text { findings: } \\
\text { challenges }\end{array}$ & $\begin{array}{l}\text { A significant power/ knowledge } \\
\text { differential within the ICMA } \\
\text { governing board, reflect- } \\
\text { ing differences in power and } \\
\text { knowledge between different } \\
\text { stakeholders within the water } \\
\text { management area }\end{array}$ & $\begin{array}{l}\text { Weak support for the CM team } \\
\text { from senior members of DWAF } \\
\text { KZN }\end{array}$ & $\begin{array}{l}\text { Poor integration between the } \\
\text { three teams within WM:IG - } \\
\text { CMA, WUA, and stakeholder } \\
\text { engagement } \\
\text { Varied understandings of the } \\
\text { challenges of the institutional } \\
\text { reform process } \\
\text { - Significantly under-resourced } \\
\text { department, given the ambition } \\
\text { and scale of the reform pro- } \\
\text { gramme }\end{array}$ \\
\hline
\end{tabular}


('adaptive IWRM'). These insights were based not only on our own experiences, but also on the work of a network of researchers across the EU (SLIM, 2004; Pahl Wostl, 2007), some of these also working in a developing country context (Mehta et al., 2007; Lankford et al., 2007), and some of whom we had worked with closely (Collins et al., 2005; Collins and Ison, 2007).

These action researchers place particular emphasis on the applied sciences of complexity and inter-disciplinarity, and on designs such as social appraisal (Stirling et al., 2007), social learning (SLIM, 2004; Steyaert and Jiggins, 2007), systemic action research (Burns, 2007) and whole system development (Weisbord and Janoff, 1995; Wilkinson and Appelbee, 1999; Attwood et al., 2003), that can work effectively in multi-stakeholder situations characterised by complexity, uncertainty, multiple interdependencies and/or the potential for conflict. We drew on these designs both in a light-touch way in the $1^{\text {st }}$ cycle of our inquiry (Table 1a, b, c), and in more depth in the $2^{\text {nd }}$ cycle.

The following were notable outcomes of this first inquiry cycle:

- Participants responded well to the action and social learning approaches: in particular these were experienced as valuing of participants' daily practices and created a space for participants to further explore their practices in creative rather than restrictive (performance management-driven) ways.

- Participants responded well to the collaborative approach to capacity building, as it enabled them and us to 'make sense' together of what was going on, and which capacity-building approaches might work best for the particular circumstances in which participants found themselves.

In addition, working within each of three main capacity building 'sites' - the Inkomati CMA; DWAF (KZN) and DWAF (Pretoria: WM:IG) (Table 1d, e), significant opportunities and challenges were identified. These were selected as the basis for the second cycle of inquiry.

\section{Design features for the $2^{\text {nd }}$ cycle of inquiry: December 06 - March 09}

(This $2^{\text {nd }}$ cycle of inquiry involved all the authors of this paper)

Design work for the $2^{\text {nd }}$ cycle of inquiry developed during the final months of the first cycle (Fig. 1). Working closely with DWAF (Pretoria: WM: IG), DWAF (KZN) and the Inkomati CMA, it was agreed that the $2^{\text {nd }}$ cycle would continue to work with groups of staff in the three pathfinder 'sites' and would develop a deeper and more consistent, (mini)-cyclic pattern of engagement within each of these (essentially, working intensively with each site over a $3 \mathrm{~d}$ period every 6 to 12 weeks). This would allow for a process of intense, active engagement and learning, followed by a period in which staff in each site could pursue/ put into practice their learning focus, while the facilitators reflected on and wrote up the outcome of their interventions and planned and prepared for the next series. The lessons learned from implementation between capacity-building interventions provided an opportunity for action learning by all participants.

In parallel with this design work, additional funding was sought for this next cycle of inquiry, partly in anticipation of the phased withdrawal of the Defra (PAWS) funding which had supported the $1^{\text {st }}$ cycle. A new funding package was agreed with the UK's Foreign and Commonwealth Office (FCO) in April 2007 (funding was provided to the Environment Agency and to the South African NGO Khanya-aicdd through the FCO's Global Opportunities Fund: Sustainable Development), with matched funding from DWAF (Pretoria) and, subsequently, from the ICMA. With a focus on water governance, this new cycle of inquiry was launched as the flagship project of the UK - South Africa Sustainable Development Dialogues (As part of a broader, 3-year, £10m funding package to support sustainable development dialogues between the UK and China, India, Brazil, Mexico and South Africa) giving it a significant profile).

In negotiating the $2^{\text {nd }}$ inquiry cycle, two key areas of focus emerged - how to build capacity for a co-operative (multi-stakeholder) approach to water governance, and how to build capacity for an approach to water governance which was at the same time adaptive. As well as being enshrined in South Africa's constitution, the principle of co-operative governance is seen as key to enabling CMAs to implement their core functions, which include co-ordinating the activities of water users and water management institutions within their water management area, promoting community participation, and involving water stakeholders in the development of a catchment management strategy. For WUAs also, the principle of co-operative governance is key to building engagement between white commercial farmers and emerging black farmers, as well as (in some cases) engaging with a wider set of stakeholder interests including local government and environmental interests. The principle of adaptive governance is less well articulated in South African water policy. Its clearest exposition can be found in the Draft Position Paper for Water Allocation Reform (DWAF, 2005) and in the Guidelines for Catchment Management Strategy Development (DWAF, 2007a).

Figure 2 illustrates the overall design of the $2^{\text {nd }}$ inquiry cycle, both as agreed initially with the FCO in April 2007, and with additional strands that had developed by April 2008, as new questions and conversations had developed. This design is characterised by several, interconnected strands of capacity building activity:

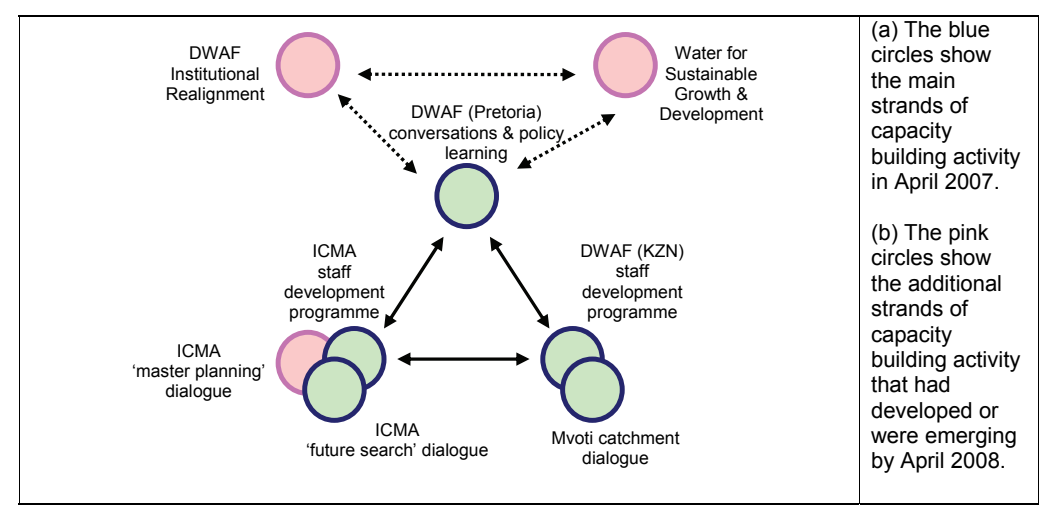

Figure 2

Diagram showing the main strands of capacity building activity in the $2^{\text {nd }}$ cycle of the Watercourse inquiry 
- Two staff development programmes, each comprising a series of 8 workshops, with a focus on the development of design and facilitation skills for multi-stakeholder, interdisciplinary dialogue processes (one staff development programme to support staff within DWAF KZN; the other to support staff within the ICMA)

- Two stakeholder dialogues, one in the Inkomati and one in the Mvoti to Umzimkulu Water Management Area (KZN), each designed to address a practical set of issues facing water stakeholders. The context for the Inkomati dialogue is the development of the Inkomati Catchment Management Strategy while, for the Mvoti dialogue, it is the agreement of institutional arrangements for the management of water resources across the sub-catchment, in particular the option to create one or more WUAs.

- Local/regional learning fed back into DWAF head office (Pretoria) policy-learning processes

- Exploring a partnership approach to the delivery of these capacity-building processes through progressive engagement with key NGOs and consultancies in South Africa.

In the remainder of this paper we focus on the two stakeholder dialogues in the Inkomati and the Mvoti, outlining how we approached these, how they developed, and emerging findings and lessons.

\section{The Inkomati stakeholder dialogue}

Consistent with the objectives of the second inquiry cycle, the design and facilitation of both dialogues has been delivered through an international collaboration between the Environment Agency (EA), two South African NGOs (Khanya-aicdd, the Mvula Trust)and the South African consultancy Cinnabar, as a result drawing new 'process' capacity into the water sector (While the Mvula Trust is an established NGO within the South African water sector, Khanya-aicdd focuses on sustainable livelihoods, Cinnabar on whole- system approaches to development. The facilitator team leading the Inkomati dialogue comprises John Goss (Cinnabar), Dumisani Ncala (Cinnabar), Geraldine Klarenberg (Mvula) and John Colvin (EA). Sizile Ndlovu is the 'client' partner for the process. The facilitator team leading the Mvoti dialogue comprises John Colvin, Sam Chimbuya (Khanya) and Mark Everard (EA). From March - November 2007, Faeeza Ballim was the client partner for the process; from December 2007 this role was taken by Pravitha Jairam).

In both sites, the developmental process adopted has been informed by a similar set of approaches, drawn from the broad social appraisal/social learning/whole system development portfolio outlined earlier. In the Inkomati we have worked primarily with the whole system approach known as 'future search' (Weisbord and Janoff, 1995; 2007), while in the Mvoti we have drawn on the 'U-process' (Kahane and Jaworski, 2005; see also Biggs et al., 2008) and social appraisal (Stirling et al., 2007) as guiding metaphors and design principles.

Detailed descriptions of the Inkomati Water Management Area (IWMA) can be found in DWAF (2004a: 171-175) and other sources. Situated in the north-eastern part of South Africa, it comprises three catchments: the Sabie-Sand, Crocodile and Komati. Economic activity is mainly centred on irrigated agriculture and afforestation, with related industries and commerce, and a strong eco-tourism industry. The Kruger National Park is a key feature of the area. Current estimates indicate considerable need for water allocation reform and water conservation and demand management, in order to maintain water security in the IWMA, particularly in the Crocodile and Komati (DWAF, 2004a).

The proposal for the Inkomati dialogue was developed through conversations with the ICMA governing board, who in 2006 suggested that better relationships between the major stakeholder groups would need to be built if a strategy (ICMS) for managing water resources across the IWMA was to be agreed and owned by these groups. In August 2006 John Colvin introduced to the board the idea of developing a multistakeholder dialogue based on Future Search principles to begin to address this concern. Eventually, the board agreed in March 2007 to a 3d event with an IWMA-wide focus, to be preceded and followed with a series of 5 sub-catchment workshops (Fig. 3).

The first series of sub-catchment workshops was held during June - August 2007, their purpose being to raise the profile of the ICMA, to engage participants through an exploration of their uses of water and stakes in the catchment, and to begin to build a picture of the catchment as a system comprising ecological, social and economic interdependencies. A total of approximately 350 participants attended these workshops, with good attendance from emerging farmers, community development workers, community-based organisations and some government departments, but (with the exception of the Crocodile workshop) poor attendance by large business users, commercial farmers, local municipalities and water boards. The bias was therefore generally towards attendees representing groups not already enjoying water allocation.

The main Future Search workshop was held over $3 \mathrm{~d}$ in October 2007 and attended by approximately 55 to 60 delegates, with similar patterns of stakeholder representation. Nonetheless, the workshop represented an important step towards developing a common understanding of the pressures facing the catchment and agreeing equitable and sustainable ways of sharing the catchment's precious water resources.

An important and widely appreciated feature of the workshop was that stakeholders experienced working through a participative process to produce a shared vision, rather than being consulted on someone else's. All of the following 9 key elements of this shared vision were agreed:

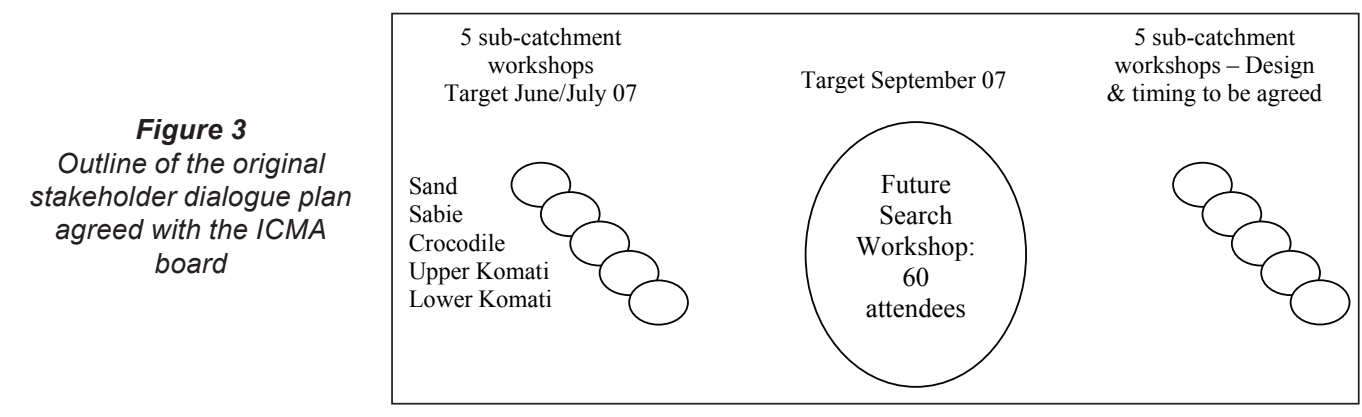


- All stakeholders actively working together - improved stakeholder co-operation

- Quality of river and ecosystems improved - less pollution greater environmental awareness

- Equitable distribution of water to all stakeholders

- Improved infrastructure for water distribution

- Capacity and skills development - emerging farmers becoming commercially empowered

- Recognition of the role and importance of the ICMA

- Improved governance and compliance with legislation

- Improved gender balance

- Job creation though tourism.

This vision will be used to help shape the ICMS and will be further tested and refined in each of the IWMA's 5 subcatchments.

Finally, some significant shifts in relationships were noted during the workshop. These included:

- Shifts in the overall willingness of all stakeholders present to co-operate [overcoming initial mistrust]

- Sharing of expertise between the [relatively few] commercial farmers present with emerging farmers - skills transfer and empowerment

- Recognition of the important role for the ICMA in facilitating a shared future for all stakeholders.

\section{The Mvoti stakeholder dialogue}

Detailed descriptions of the Mvoti sub-catchment can be found in DWAF (2004b). The sub-catchment forms the northern border of the Mvoti to Umzimkulu Water Management Area and consists mainly of commercial timber in the upper reaches, subsistence agriculture dominating communal land inland around Maphumulo and sugar cane towards and along the coastal strip. With a predominantly rural population, irrigated agriculture and industry are the main water uses in the catchment, followed by afforestation and domestic use. Owing to the lack of significant storage in the catchment and the water requirements which exceed the available resource, the catchment is considered to be stressed.

The idea of a dialogue process with stakeholders in the Mvoti sub-catchment developed out of the conversations held with the DWAF KZN catchment management team during the first inquiry cycle (Table 1d). These discussions focused on the history of the team's work in the Mvoti over previous years and the difficulties they had experienced in supporting effective transformation of the two Irrigation Boards (IBs) in the catchment(Upper Mvoti Irrigation Board and Lower Mvoti Irrigation Board). It was agreed that the Watercourse project would seek to develop a stakeholder dialogue process to explore options for institutional arrangements in the Mvoti catchment, with a view both to the transformation of the two Irrigation Boards and to seek wider benefit for communities across the catchment. At the same time, this would create a 'site of learning' for the DWAF KZN catchment management team.

An early success of the dialogue was that stakeholders from the upper Mvoti (including the Upper Mvoti IB), the central Mvoti tribal communities, the lower Mvoti (including the Lower Mvoti IB) and the catchment-wide Mvoti Stakeholder Forum, agreed to work together through a dialogue process. Recognising environmental, social and economic interdependencies across the catchment, they also agreed to work together to explore the option of a single institutional arrangement for the Mvoti (WUA or variation on this). Another early agreement in the dialogue

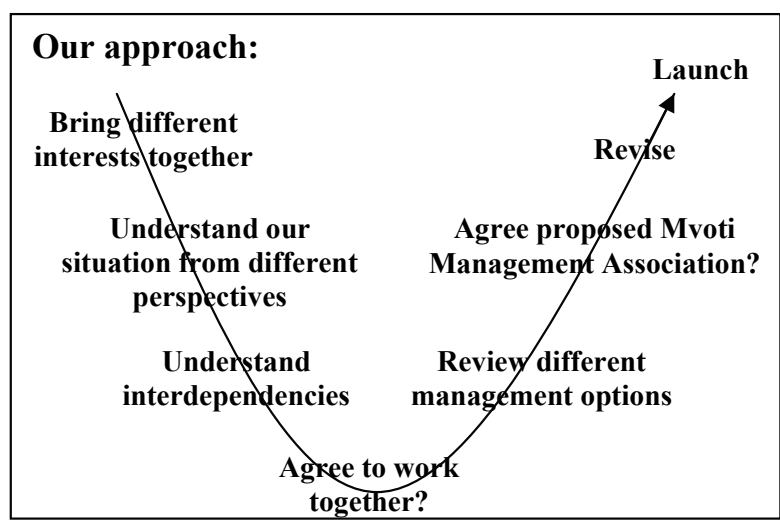

Figure 4

$U$-process metaphor, used to frame the Mvoti dialogue (after Kahane and Jaworski, 2005)

has been to involve a wider cross-section of stakeholders before different options are fully explored, resulting in a workshop for 50 to 60 stakeholders in March 2008. One key to the effectiveness of the process to date has been the shared understanding that building common understanding across diverse interests takes time if it is to succeed, and that this up-front investment of time could bring substantial benefits in the longer term. The 'U-process' metaphor (Kahane and Jaworski, 2005) has helped to frame this understanding, and to create a 'holding framework' for the dialogue as a whole (Fig. 4).

\section{Local lessons drawn from our capacity building work in the Inkomati and Mvoti}

We are mindful of the fact that the two stakeholder dialogues reported in this paper are still in progress (at the time of writing (March 2008), both were expected to continue for a further 12 months). Nonetheless, a number of observations can be made at this stage.

In the Inkomati, we have not only facilitated the development of a shared vision for the IWMA (a key element of the ICMS), but have also done so in a way which is participative rather than consultative. Their valuing of this approach is reflected by stakeholders in their vision, which speaks of '.. all stakeholders actively working together - improved stakeholder co-operation'. Experiencing this approach has also been of particular significance to the institutional development team in the ICMA. Initially viewing the Future Search Process as imposing unreasonable demands on their time, they have come to strongly appreciate this way of working, including the importance of careful design work leading up to stakeholder events (Joseph Mabunda and Dudu Thwala, as stated at the $2^{\text {nd }}$ Inkomati 'master planning' workshop, 27 ${ }^{\text {th }}$ November 2007 (see Colvin, 2007a)).

In addition, engaging across significant elements of the IWMA 'stakeholder system' has enabled the facilitator team to provide strategic feedback to the board and senior management team at the ICMA. For example:

- Over the past 12 months we have observed a great many stakeholder workshops taking place across the catchment, e.g. workshops on water allocation reform, stakeholder empowerment, vision development and CMS development, with little overall sense of coordination or common narrative.

- There is considerable variation in the style of these workshops, some being done 'to' stakeholders, some with stakeholders (and some 'to' the ICMA, some with the ICMA). 
- This has placed considerable stress on the ICMA institutional development team with responsibility to coordinate these activities, as well creating a high potential for 'stakeholder fatigue' and confusion.

As a result of these observations, we have recently begun to address some of these issues through the development of a 'master planning' process bringing together the ICMA, DWAF (Pretoria), DWAF (Mpumalanga), the CMS development team and some of the other public service providers working for the them (Fig. 2(b); Colvin et al., 2008).

The issue that the Future Search Process has found most difficult to address is that of non-attendance / engagement of some groups of stakeholders. There is an irony in this, given that Future Search is specifically designed to bring together 'those with authority, resources, expertise, information and need' in relation to a common set of issues (Weisbord and Janoff, 2007). The main reason for this seemed to be that those with responsibility for recruiting key sectors to the stakeholder events including members of the ICMA governing board - failed fully to appreciate the significance of their role in the process; there is clearly an opportunity to learn from this.

The Mvoti dialogue is taking place at a more local level than that of the Inkomati dialogue. This provides for a clearer definition both of stakeholder interests and of interdependencies and perhaps accounts for our greater success to date in bringing all the interests we have identified as relevant 'into the room together'. As in the Inkomati, the dialogue has also provided an important focus for capacity building for DWAF KZN staff - to date, this has involved learning through observation and reflection, and has yet to reach the stage of testing these lessons in participants' own practice.

Perhaps the most significant challenge facing the facilitator team in developing the Mvoti dialogue is finding the appropriate set of 'languages' through which to facilitate it. Finding the right balance of language and style is particularly important given the involvement of tribal community members as well as the broad mix of environmental, social and economic interests involved. We continue to experiment with this. So far the process has laid emphasis on a combination of participative diagramming and model building (for example for working out together how the catchment functions as a single ecosystem), and on 'expert presentations'. Our observation is that the presentations to date have tended to favour engineering and economic knowledge over other types.

\section{Lessons for national policy and processes in South Africa}

The two dialogues described in this paper have demonstrated some early successes in enabling different stakeholder groups to engage in dialogue around issues of shared interest based on a common resource. The dialogue processes are both still at an early stage, but the approaches used, drawing eclectically from a range of social learning practices, have so far proven robust. At the same time we recognise that there are still considerable challenges to address in terms of building dialogue between less and more powerful groups, and that this will continue to test our skilfulness and ingenuity in drawing on appropriate 'languages' through which to create inter-disciplinary dialogue.

Nonetheless, we have been able to explore and demonstrate approaches to capacity building both of stakeholders and of ICMA and DWAF staff that are based on an interactive rather than passive model of learning, opening up spaces for 'making sense' of progressive policies seeking to create change in complex situations against a background of highly uneven development.

We contend that experiments of this type are critical if DWAF is to implement its progressive water laws and policies effectively. The implications of this are substantial and we recommend that these are explored in the context of two current developments in the DWAF institutional and policy landscape. The first of these is the Minister's Institutional Realignment Review; the second is the Water for Sustainable Growth and Development Initiative (Fig. 2(b)).

The Minister's Institutional Realignment Review was initiated in June 2007 to address a range of concerns, including: the number of institutions that DWAF is committed to establishing under the National Water Act; the capability of DWAF to support these structures; the relevance of these institutions within the current environment; and the slow pace of transformation especially at the WUA level (DWAF, 2007b). This review, which is due for conclusion in October 2008, included a key workshop in October 2007 at which a shared commitment to CMA development was established, supported by common agreement on the need for the accelerated transformation of the DWAF national and regional offices in order to properly resource the new CMAs. Work has since been under way to agree whether to proceed with the original model of 19 CMAs, or whether to set up a smaller number (Kubheka, 2008).

While this review has been important in reinforcing commitment to the institutional realignment process set out in the National Water Act, we would contend that the focus on institutions and structures needs to be balanced with thinking through the much harder task of capacity building for implementation. Our recommendation to this review has been that it should spend less time deliberating about structures and, instead, focus more of its attention on prioritising and designing processes for learning about how to do adaptive IWRM at the CMA, WUA and community levels (Colvin, 2007b). From our experiences in the Inkomati and Mvoti, this should comprise at least the following two elements:

- Encouraging further experimentation in interactive approaches to capacity building of the type we have been exploring. This could involve, for example, setting up pathfinders in all eight of the WMAs in which CMAs have been established.

- Developing an architecture of learning (for example through managed learning networks (Warburton et al., 2007)), in which learning can firstly be shared between pathfinders then subsequently 'scaled out' to other WMAs.

A further recommendation is that DWAF (Pretoria) invests effort in exploring and agreeing on a policy narrative for this kind of adaptive capacity building approach. The 'Water for Sustainable Growth and Development' initiative (DWAF, 2008a), which will in turn shape the 2009 review of the National Water Resources Strategy, provides a valuable opportunity in which to do this. This initiative has already started to conceptualise Water for Sustainable Growth and Development (WfSGD) as involving interaction between four different policy narratives, as shown in Fig. 5a (DWAF, 2008b). By re-casting Fig. 5a in terms of adaptive dialogue between these policy narratives, as in Fig. 5b, we can start to represent the kinds of dialogic, capacity-building approaches we have been undertaking locally, within a national policy framework. 


\begin{tabular}{|c|c|c|c|}
\hline $\begin{array}{l}\text { ENVIRONMENT } \\
\text { - Climate change impact } \\
\text { - Water security \& shock } \\
\text { mitigation } \\
\text { - IWRM } \\
\text { - Sustainable water use } \\
\text { - Biodiversity \& ecological } \\
\text { protection } \\
\text { - Land use \& management }\end{array}$ & $\begin{array}{l}\text { SPATIAL DEVELOPMENT } \\
\text { - Population demographics } \\
\text { - Infrastructure } \\
\text { - Services } \\
\text { - Built environment - } \\
\text { housing / construction } \\
\text { - Energy (esp hydro) } \\
\text { - Transport }\end{array}$ & $\begin{array}{l}\text { ENVIRONMENT } \\
\text { - Climate change impact } \\
\text { - Water security \& shock } \\
\text { mitigation } \\
\text { - IWRM } \\
\text { - Sustainable water use } \\
\text { - Biodiversity \& ecological } \\
\text { protection } \\
\text { - Land use \& management }\end{array}$ & $\begin{array}{l}\text { SPATIAL DEVELOPMENT } \\
\text { - Population demographics } \\
\text { - Infrastructure } \\
\text { - Services } \\
\text { - Built environment - } \\
\text { housing / construction } \\
\text { - Energy (esp hydro) } \\
\text { - Transport }\end{array}$ \\
\hline & & \multicolumn{2}{|c|}{ Integration using an adaptive IWRM approach } \\
\hline ECONOMIC GROWTH & SOCIAL DEVELOPMENT & ECONOMIC GROWTH & SOCIAL DEVELOPMENT \\
\hline $\begin{array}{l}\text { - Agriculture } \\
\text { - Mining } \\
\text { - Industry } \\
\text { - Manufacturing } \\
\text { - Commerce \& business } \\
\text { - Tourism \& recreation } \\
\text { - Property development }\end{array}$ & $\begin{array}{l}\text { - Poverty eradication } \\
\text { - Improved livelihoods } \\
\text { - Job creation \& SMMEs } \\
\text { - Health \& hygiene } \\
\text { - Food security } \\
\text { - Combating HIV\&AIDS } \\
\text { - Gender mainstreaming }\end{array}$ & $\begin{array}{l}\text { - Agriculture } \\
\text { - Mining } \\
\text { - Industry } \\
\text { - Manufacturing } \\
\text { - Commerce \& business } \\
\text { - Tourism \& recreation } \\
\text { - Property development }\end{array}$ & $\begin{array}{l}\text { - Poverty eradication } \\
\text { - Improved livelihoods } \\
\text { - Job creation \& SMMEs } \\
\text { - Health \& hygiene } \\
\text { - Food security } \\
\text { - Combating HIV\&AIDS } \\
\text { - Gender mainstreaming }\end{array}$ \\
\hline
\end{tabular}

Figure 5a

Diagram showing the four key policy narratives that will need to be addressed through the WfSGD initiative

Much more work needs to be done on working out simple devices, as in Fig. 5, for conceptualising this shift in approach from top-down to interactive capacity-building approaches, and in developing a policy narrative around this. And there may be lessons to be learned here from Europe, which is starting to explore policy narratives in terms of social learning (Environment Agency, 2006), transition management (Van der Brugge and Rotmans, 2007) and adaptive IWRM (CAIWA, 2007).

\section{International lessons}

In a world designed around engineering principles, IWRM can be understood as a blueprint, a management design that is worked out on paper and then imposed on reality. In a world shaped through processes of learning and social adaptation, IWRM is no longer a 'thing' to do, but instead becomes an interactive and emergent process of adaptive water resources managing, seeking wherever possible to make integrative connections and to build concerted and inter-disciplinary action (Collins and Ison, 2007).

There are no easy recipes for developing these approaches, whether in 'developed' or 'developing' country contexts. These processes will take different forms in different countries, depending on local capacities, contexts and developmental trajectories (Lankford et al., 2007). But, in a climate changing world, the call for these new forms of adaptive managing processes becomes increasingly urgent.

\section{References}

ATTWOOD M, PEDLER M, PRITCHARD S and WILKINSON D (2003) Leading Change: A Guide to Whole Systems Working. Policy Press, Bristol, UK.

BIGGS H, BREEN C and PALMER C (2008) Engaging a window of opportunity: Synchronicity between a regional river conservation initiative and broader water law reform in South Africa. Int. J. Water Resour. Dev. 24 (3) 329-343.

BURNS D (2007) Systemic Action Research: A Strategy for Whole System Change. Policy Press, Bristol, UK.

CAIWA (2007) International Conference on Adaptive and Integrated Water Management: Coping with Complexity and Uncertainty, November 2007, Basel, Switzerland.

CHALMERS H and COLVIN J (2005) Addressing environmental inequalities in UK policy: An action research perspective. Local Environ. 10 (4) 333-360.

Figure $5 b$

Diagram indicating the value of adaptive dialogue as a means to develop a progressively integrated narrative for WfSGD, drawing on the four key policy narratives

COLLINS K, ISON R and BLACKMORE C (2005) River Basin Planning: Social Learning. Science Report SC050037. Environment Agency, Bristol, UK.

COLLINS K and ISON R (2007) Trusting Emergence: Some Experiences of Learning About Integrated Catchment Science with the Environment Agency of England and Wales. Paper presented at the first CAIWA Conference, Basel, November 2007.

COLVIN J (2007a) Report of the Inkomati 'Masterplan' Workshop 2, November 2007. Inkomati Catchment Management Agency, Nelspruit, South Africa.

COLVIN J (2007b) DWAF Institutional Realignment - Feedback from the Environment Agency (England \& Wales), November 2007. Report to Ms Lindiwe Hendricks, Minister of Water Affairs and Forestry. DWAF, Pretoria, South Africa.

COLVIN J, EVERARD M, GOSS J, KLARENBERG G and NCALA D (2008) Building Capacity for Adaptive and Integrated Water Resources Governance in the Inkomati. Inkomati Catchment Management Agency, Nelspruit, South Africa.

CULLIS J and VAN KOPPEN B (2007) Applying the Gini Coefficient to Measure Inequality of Water Use in the Olifants River Water Management Area, South Africa, Research Report 113. International Water Management Institute (IMWI), Colombo, Sri Lanka.

DWAF (DEPARTMENT OF WATER AFFAIRS AND FORESTRY) (2003) Strategic Framework for Water Services. DWAF, Pretoria, South Africa.

DWAF (DEPARTMENT OF WATER AFFAIRS AND FORESTRY) (2004a) National Water Resources Strategy. DWAF, Pretoria, South Africa.

DWAF (DEPARTMENT OF WATER AFFAIRS AND FORESTRY) (2004b) Internal Strategic Perspective: Mvoti to Mzimkulu Water Management Area. Prepared by Tlou \& Matji (Pty) Ltd, WRP (Pty) Ltd and DMM (cc) on behalf of the Directorate National Water Resource Planning (East). DWAF Report No. PWMA $11 / 000 / 00 / 0304$

DWAF (DEPARTMENT OF WATER AFFAIRS AND FORESTRY) (2005) Draft Position Paper for Water Allocation Reform. DWAF, Pretoria, South Africa.

DWAF (DEPARTMENT OF WATER AFFAIRS AND FORESTRY) (2006) Minutes of the Top Management Committee Meeting No. 14/2006 held on Monday 29 May 2006, Pretoria, South Africa.

DWAF (DEPARTMENT OF WATER AFFAIRS AND FORESTRY) (2007a) Guidelines for the Development of Catchment Management Strategies: Towards Equity, Efficiency and Sustainability in Water Resources Management. By Pollard S, du Toit D, Reddy Y, Tlou T. DWAF, Pretoria, South Africa.

DWAF (DEPARTMENT OF WATER AFFAIRS AND FORESTRY) (2007b) Concept Note: Institutional Realignment Workshop, October 2007. 
DWAF (DEPARTMENT OF WATER AFFAIRS AND FORESTRY) (2008a) Discussion Document on Water for Growth and Development, Poverty Alleviation and Its Impact on the Socio-Economic Sector. Paper to Cabinet Legotka, January 2008.

DWAF (DEPARTMENT OF WATER AFFAIRS AND FORESTRY) (2008b) Water for Growth and Development: Overview, Internal Memo, February 2008. DWAF, Pretoria, South Africa.

EC (EUROPEAN COMMISSION) Water Framework Directive (Directive 2000/60/EC of 23 October 2000 Establishing a Framework for Community Action in the Field of Water Policy).

ENVIRONMENT AGENCY (2006) Water for Life and Livelihoods: A Framework for River Basin Planning in England and Wales. Environment Agency, Bristol, UK.

GWP (GLOBAL WATER PARTNERSHIP) (2000) Integrated Water Resources Management. GWP Technical Committee Background (Paper 4). GWP, Stockholm, Sweden.

ICWE (INTERNATIONAL CONFERENCE ON WATER AND THE ENVIRONMENT) (1992) The Dublin Statement on Water and Sustainable Development. International Conference on Water and the Environment, Dublin, Ireland.

KAHANE A and JAWORSKI J (2005) The U-Process: A social technology for addressing highly complex challenges. Generon Consulting, Boston, USA.

KHANYA-AICDD, Southern Africa Trust (2007) Learning about Action Learning. Khanya-aicdd, Johannesburg, South Africa.

KUBHEKA V (2008) Institutional Realignment Project: Emerging Institutional Models for Water Sector in South Africa. Draft 001, July 2008. Pretoria: DWAF.

LANKFORD BA, MERRY DJ, COER J and HEPWORTH N (2007) From Integrated to Expedient: An Adaptive Framework for River Basin Management in Developing Countries, Colombo, Sri Lanka: IWMI (International Water Management Institute).

MEHTA L, MARSHALL F, MOVIK S, STIRLING A, SHAH E, SMITH A and THOMPSON J (2007) Liquid Dynamics: Challenges for Sustainability in Water And Sanitation, STEPS Working. Paper 6. STEPS Centre, Brighton, UK.

O'KEEFFE J, UYS M and BRUTON M (1992) Freshwater Systems. In: Fuggle R and Rabie M (eds.) (1992) Environmental Management in South Africa. Juta \& Co, Johannesburg, South Africa.

ORR P, COLVIN J and KING D (2007) Involving stakeholders in integrated river basin planning in England and Wales. Water Resour. Manage. 21 331-349.

PAHL-WOSTL C (2007) Transitions towards adaptive management of water facing climate and global change. Water Resour. Manage. 21 49-62.
RABIE M and DAY J (1992) Rivers. In: R Fuggle R and Rabie M (eds.) (1992) Environmental Management in South Africa. Juta \& Co, Johannesburg, South Africa.

REASON P and BRADBURY H (eds.) (2001) Handbook of Action Research: Participative Inquiry and Practice. Sage Publications, London, UK.

RSA (REPUBLIC OF SOUTH AFRICA) (1997) Water Services Act. Complete Reference. Government Gazette, South Africa.

RSA (REPUBLIC OF SOUTH AFRICA) (1998) National Water Act. Act No. 36 of 1998. Government Gazette, South Africa.

STEYAERT P and JIGGINS J (2007) Governance of complex environmental situations through social learning: a synthesis of SLIM's lessons for research, policy and practice. Environ. Sci. Pol. 10 (6) 575-586.

STIRLING A, LEACH M, MEHTA L, SCOONES I, SMITH A, STAGL S and THOMPSON J (2007) Empowering Designs: Towards More Progressive Appraisal of Sustainability, STEPS Working Paper 3. STEPS Centre, Brighton, UK.

THE SLIM PROJECT (2004) Social Learning as a Policy Approach for Sustainable Use of Water. A field-tested framework for observing, reflecting and enabling, SLIM Framework (Accessed at http://slim. open.ac.uk).

TURTON A (2007) Can We Solve Tomorrow's Problems with Yesterday's Experiences and Today's Science? CSIR, September 2007.

VAN DER BRUGGE R and ROTMANS J (2007) Towards transition management of European water resources. Water Resour. Manage. (2007) 21 249-267.

VAN KOPPEN B, MORIARTY P and BOELEE E (2006) Multiple-Use Water Services to Advance the Millennium Development Goals, Research Report 98.: International Water Management Institute, Colombo, Sri Lanka.

WARBURTON D, PEDLER M and WILKINSON D (2007) Improving poor Environments: The Role of Learning Architectures in Developing and Spreading Good Practice. Science Report: SC050018/ SR3. The Environment Agency, Bristol, UK.

WEISBORD M and JANOFF S (1995) Future Search: An Action Guide to Finding Common Ground in Organisations and Communities. Berrett-Koehler, San Francisco, USA.

WEISBORD M and JANOFF S (2007) Don't Just Do Something, Stand There! Ten Principles for Leading Meetings that Matter. Berrett Koehler, San Francisco, USA

WILKINSON D and APPELBEE E (1999) Implementing Holistic Government: Joined-Up Action on the Ground. The Policy Press, Bristol, USA. 